\title{
Power engineering challenges in Zambia
}

\author{
Elena Gorkaltseva ${ }^{1, *}$, Uchivyo Sinkala ${ }^{1}$ \\ ${ }^{1}$ National Research Tomsk Polytechnic University, 634050 Tomsk, Russia
}

\begin{abstract}
The paper presents a review of current power engineering challenges in Zambia in relevance to the required potential necessary for the country's modern economic development. An outline of the energy sector is provided. The driving need for enhancing the development of the energy sector is highlighted, accounted by the country's annual increase of GDP, leading to an increase in electricity demand. Possible mitigations are suggested, with the development of Zambia's rich potential in renewable energy, as well as upgrading the operating power plants and constructing more off-grid and on-grid generating facilities.
\end{abstract}

\section{Introduction}

Generating electricity can be used to represent the reality of human intellect. Constituting a physical phenomenon of moving electrons, it is empowered in energy as a thermodynamic quantity equivalent to the capacity of a physical system to do work. As the human effort is slowly being replaced by machines that require scientific energy (power), so the need for a country to develop or do some adjustments in the energy sector increases. Power generation has an enormous impact on the people around, or a country in general. Unfortunately, in some countries electrical energy is still an Olympic gold medal.

Zambia, a Southern African country, has the size of 752.681 square kilometers, a population close to 15 million. These facts result in a conflicting statement, since the vast territory for the specified number of people could be viewed as a favorable factor for the country's development. Nonetheless, a vast majority of land is still virgin, and only segmented portions of it are densely populated. Zambian economy is predominantly determined by mining, agriculture, manufacturing, and tourism.

Zambia, which won its independence in 1964, has the heritage of a few decades of oneparty socialist government. The country is currently a multi-party democracy state and has been going through a period of economic and political reforms, many of which have affected the energy sector. Back in 1991 the government started privatizing state-owned enterprises, trying to increase their performance.

However, its feats for modernizing its economy have not been as effective as they should be, due to its inadequate supply of power. The country's GDP has been increasing at the rate above $6 \%$ [1], which technically has shown that each year there is a $3 \%$ increase in electricity demand [2].

\footnotetext{
* Corresponding author: elena gork@mail.ru
} 
According to the estimates done in 2014, electrification rate in Zambia was extremely low - at $22 \%$ with $45 \%$ city dwellers and only $3 \%$ of people in rural areas [1]. It has slightly improved since then. Still, only about $25 \%$ of the total population have access to electricity, while many people have to rely on kerosene and candles almost every single day. The current situation in power supply in Zambia is described as energy crisis.

\section{Energy sector review}

Zambia's energy resource potential includes bio-energy resources, hydro, solar, wind and geothermal power. In spite of its richness, the potential in power generation and supply needs to be enhanced and balanced.

The primary energy source for the majority of people is biomass (firewood and char coal), which builds up $80 \%$ of supply. It is relied on to cover people's needs for cooking and heating, and accounts for over $70 \%$ of energy consumption (with $57 \%$ of urban populations and $97 \%$ in rural communities) [1].

The major source of electrical energy in Zambia is hydro power, which cumulatively account for about $95.9 \%$ of the total installed electricity generation in the country [3, 4]. Hydro power only covers $12 \%$ of the energy needs [1].

The generation of electricity in the country is predominantly carried out by three hydro power stations: Victoria Falls Power Station, Kariba North Bank, Kafue Gorge. The Victoria Falls Power Station, comprising 3 power stations, has the total capacity of 108 MW. The Kariba North Bank, one of the world's biggest man-made reservoirs, currently supplies about 720 MW of power; The Kafue Gorge generates 900 MW of electricity. However, the installed capacity of some of these power plants is higher [2].

Table 1. Major Power Stations in Zambia.

\begin{tabular}{|c|c|}
\hline Power station & $\begin{array}{c}\text { Installed } \\
\text { Capacity }\end{array}$ \\
\hline The Victoria Falls Power Station & $108 \mathrm{MW}$ \\
\hline The Kariba North Bank & $1080 \mathrm{MW}$ \\
\hline The Kafue Gorge & $990 \mathrm{MW}$ \\
\hline
\end{tabular}

All these three major suppliers of the country's power are owned by ZESCO (Zambia Electricity Supply Corporation) [3], the largest power producer. So far, it has experienced considerable difficulties in meeting the demands of the country's growing economy. Hydro power generation potential in Zambia is theoretically estimated to be 6000 megawatts [2]. However, it has not been employed to its full, with only $1700 \mathrm{MW}$ currently exploited [1]. A considerable impediment in sustainable reliance on hydropower is dependence on rainfall $[5,6]$, among other factors, the major one is the lack of investments for modernizing the plants.

The remaining $4.1 \%$ of the electrical energy is obtained from diesel sources and mainly covers the needs for transport, agriculture, and mining. However, the country depends heavily on export in obtaining diesel fuel.

\section{Measures to resolve energy crisis}

To alleviate the energy deficit the government has implemented the procurement programs [4]. They are known as "load shedding program" and can be regarded as one of the most unwelcomed programs in modern Zambia. The programs involve electricity supply according to revised load shedding schedules of between 5 and 6 hours for the domestic, industrial and commercial customers on a rolling basis through a 24-hour period. Only 
mines are the unaffected entities in this crisis, due to their vital role in the healthy state of the economy. Industrial produce has drastically decreased due to reduced power supply.

This incapability of ZESCO and others players in the energy sector of Zambia to meet the modern energy needs has raised concerned citizens and the government to develop measures to make the power deficit less impactful. The government has implemented policies like the" feed-in tariff policy" which involves collaboration with different stakeholders in order to increase investments in the energy sector. The construction of new and upgrading of the hydro-electric power stations are highly demanded [2].

Currently an important direction in which measures are intended and attempted to be taken is furthering the development of renewable energy sources. Zambia's potential in this area is believed to be significant $[1,2]$.

Biomass, being the major source of renewable energy, has been holding an important position in supplying energy to cover population's living needs. This energy source is rather varied and includes agricultural residues (maize, rice, wheat), forest residues, livestock waste, municipal waste $[7,8]$. Moreover, according to the conducted research, this energy source even holds favorable prospects in terms of addressing the problem of Zambia's dependence on imports of petroleum products [9].

Nonetheless, more attention should be granted to more advanced technologies, the major of which is furthering the initiated procurement process for the deployment of up to $300 \mathrm{MW}$ from solar power [10]. Solar power has a high potential in Zambia, since the country experiences about 3000 sunshine hours per year.

Another field of mitigations is increasing investment in geothermal energy, with the prospect to use the power of more than 80 hot springs. Exploring and exploiting geothermal energy is demanding in terms of cost and resources. Nowadays there is only one geothermal plant, built in late $1980 \mathrm{~s}$, operating and is planned to be upgraded for the production of 2 MW of electricity [2].

The strongest suggestion in terms of the energy crisis in Zambia is the application of decentralized energy. It means creating power-supply networks with energy sources built near the place of consumption [11]. One of the major tasks in coping with energy deficit is building mini-hydro power stations [1], especially in the North and the North-West of the country. Solutions for both on-grid and off-grid applications are supported.

The other measures are the importation of power from the neighboring countries. Zambia cooperates with a number of countries (Zimbabwe, Namibia, Tanzania, Botswana) in an interconnected grid.

\section{Conclusions}

The struggle for a modern country can best be fought with the country's electricity abundance. The following steps can be proposed to overcome the current power engineering challenges in Zambia:

- the construction of new on-grid and off-grid hydro-electric power stations, locating them near the place of consumption is highly advisable;

- upgrading the existing power stations;

- focusing on alternative sources of power, specifically solar, bio-energy sources, wind and geothermal power.

Zambia remains a remarkable investment destination in the energy sector. Its location and the development of new interconnectors coupled with power deficit in the region builds up a good export market potential.

\section{References}


1. Zambia renewables readiness assessment. (2013) Available: http://www.irena.org/DocumentDownloads/Publications/RRA_Zambia.pdf [Accessed April; 2017]

2. Energy sector profile (by Zambia Development Agency) (2014) Available: www.zda.org.zm/?q=download/file/fid/55 [Accessed April; 2017]

3. J. Kbaki. Case study in Corporate Governance: Industry Focus - Electricity. (2009) Available: https://www.oecd.org/daf/ca/corporategovernanceofstateownedenterprises/44200010.pdf [Accessed April; 2017]

4. D. Mulongoti, G. Mugala, B.Kumwenda, H. Louie, GHTC 2016 - IEEE Global Humanitarian Technology Conference: Technology for the Benefit of Humanity. Conference Proceedings, 7857324, 488 (2017)

5. B. Tembo, B. Merven, J. Energy Southern Africa, 24(2), 16 (2013)

6. K. Pilli-Sihvola, S. Väätäinen-Chimpuku, Int. J. Disaster Risk Reduction, 19, 461 (2016)

7. A. Shane, Sh.H. Gheewala, B. Fungtammasan, Th. Silalertruksa, S. Bonnet, S. Phiri, Bioenergy resource assessment for Zambia. Renewable and Sustainable Energy Reviews, 53 (2016)

8. L. German, G. Schoneveld, Rev. of Policy Research, 29 (4), 467 (2012)

9. D. Drabik, H. de Gorter, G.Timilsina, Food Policy, 59, 103 (2016)

10. K. Kornbluth, B.Pon, P. Erickson, Renewable and Sustainable Energy Reviews, 16, 6737 (2012)

11. N.L. Behnke, T. Klug, R. Cronk, K.F. Shields, K. Lee, E.R. Kelly, G. Allgood, J. Bartram. Resource mobilization for community-managed rural water systems: Evidence from Ghana, Kenya, and Zambia. J. of Cleaner Production (2017) 